\title{
RESISTENSI ATAS PENGENDALIAN TEMBAKAU TERHADAP HAK-HAK EKONOMI, SOSIAL, DAN BUDAYA DI KALANGAN PETANI SRINTHIL
}

\author{
Nurma Khusna Khanifa \\ nurma_khusna@ymail.com
}

\begin{abstract}
The World Health Organization (WHO) has indeed adopted the Framework Convention on Tobacco Control (FCTC) in the 56th World Health Assembly in 2003. The FCTC provides reference to the importance of worldwide tobacco control. The impact of this resistance is the tobacco farmers of Temanggung Regency. Tobacco planted on the slopes of Sindoro and Sumbing mountains, Temanggung Regency, is the number one tobacco producer of tobacco srinthil. Srinthil Tobacco has been listed as Geographical Indication No. ID G 000000027 at the Directorate General of Intellectual Property. Srinthil is located in the village of Legokari Tlogomulyo District has a high quality has placed it as a green gold title. Cultural heritage has left the custom of ritual in obtaining the quality of tobacco. But behind the success of tobacco as one of the commodities that have a large contribution to state revenues, the government actually issued several policies against the development of marketing. The government's appreciation of the tobacco leaf lately seems half-hearted. For farmers, tobacco is not just a commodity. Tobacco is an important part of the spiritual life. Elements of tobacco in the form of chopping, clove or cigarettes in offerings that symbolize fire, water, air and soil. Thus tobacco is considered as a balance between man and nature. The way to see the tobacco issue from a health standpoint by negating this other perspective is not only inappropriate but rather misleading. The reason is that tobacco is a legal and superior commodity that has a vital role with the linkage of economic, social and cultural interests. Therefore, the government can not yet accommodate the human rights of economic, social and cultural rights.
\end{abstract}

Keywords: tobacco, srinthil, farmers, anti-tobacco.
Abstrak
World Health Organization (WHO) memang telah mengadopsi Framework Convention on Tobacco Control (FCTC) dalam Sidang Kesehatan Dunia (World Health Assembly) ke- 
56 pada 2003. FCTC ini memberikan rujukan tentang betapa pentingnya pengendalian tembakau di seluruh dunia. Dampak yang dirasakan adanya resistensi ini ialah petani tembakau Kabupaten Temanggung. Tembakau yang ditanam di lereng gunung Sindoro dan Sumbing, Kabupaten Temanggung, sebagian adalah penghasil tembakau kualitas nomor satu, yakni tembakau srinthil. Tembakau Srinthil telah terdaftar sebagai Indikasi Geografis No. ID G 000000027 di Direktorat Jenderal Kekayaan Intelektual. Srinthil berada di Desa Legoksari Kecamatan Tlogomulyo ini memiliki berkualitas tinggi telah menempatkannya sebagai sebutan emas hijau. Warisan budaya telah meninggalkan adat berupa ritual dalam mendapatkan mutu tembakau. Tetapi dibalik kesuksesan tembakau sebagai salah satu komoditas yang memiliki sumbangsih besar terhadap penerimaan negara, pemerintah justru mengeluarkan beberapa kebijakan yang menentang terhadap perkembangan pemasaran. Apresiasi pemerintah terhadap daun tembakau belakangan nampak setengah hati. Bagi para petani, tembakau memang tak sekedar komoditi. Tembakau menjadi bagian penting dari kehidupan spiritual. Unsur tembakau berupa rajang, kretek atau rokok dalam sesaji yang melambangkan api, air, udara dan tanahal. Dengan demikian tembakau dianggap sebagai penyeimbang antara manusia dan alam. Cara melihat persoalan tembakau dari sudut pandang kesehatan dengan meniadakan perspektif lainnya ini bukan hanya tidak tepat melainkan justru menyesatkan. Alasannya, tembakau adalah barang legal dan komoditi unggulan yang mempunyai peran vital dengan pertautan kepentingan ekonomi, sosial dan budaya. Oleh sebab itu pemerintah belum bisa menjadi mengakomodir hak-hak manusia (human rights) hak-hak ekonomi, sosial dan budaya.

Kata kunci: tembakau, srinthil, petani, antitembakau.

\section{A. Pendahuluan}

Indonesia adalah negeri penghasil tembakau dan penghasil cengkeh sekaligus. Dari pengolahan dan racikan tembakau dan cengkeh inilah yang melahirkan 'rokok cengkeh', lebih dikenal dengan sebutan kretek. Identitas ini melekat pada Kudus sebagai "kota kretek" dan salah seorang pembentuk industri ini, Haji Nitisemito, dikenang sebagai "raja kretek". Identitas ini sekaligus menandakan pentingnya kedudukan industri pengolahan tembakau dan cengkeh dalam ekonomi di Indonesia, dari sebelum terbentuknya Republik Indonesia sampai sekarang. Identitas ini pula yang melekatkan kretek dengan Indonesia. ${ }^{1}$

Industri rokok kretek mengalami perjalanan yang panjang, lebih 120 tahun. Setelah melewati berbagai kesulitan, bahkan nyaris hancur berkeping-keping dalam periode singkat gelombang pasang fasisme-militerisme Jepang, industri kretek mampu bangkit kembali dan selama dua dekade terakhir mengecap masa keemasannya. Namun, lagi-lagi, kini industri kretek dihadapkan tantangan global dalam bentuk hambatan-hambatan perdagangan dengan menampakkan sosok dalam bentuk rezim kesehatan dunia bahkan berikade-berikade perdagangan yang dibentuk di

1 Nuran Wibisono, Marlutfi Yoandinas, Kretek: Kemandirian dan Kedaulatan Bangsa Indonesia, Perpustakaan Nasional: Katalog Dalam Terbitan (KDT), 2014, hal. 30. 
negerinya sendiri. ${ }^{2}$

World Health Organization (WHO) memang telah mengadopsi Framework Convention on Tobacco Control (FCTC) dalam Sidang Kesehatan Dunia (World Health Assembly) ke-56 pada 2003. FCTC ini memberikan rujukan tentang betapa pentingnya pengendalian tembakau di seluruh dunia. Dengan rujukan ini diharapkan negara-negara anggota Perserikatan Bangsa-Bangsa (PBB) berkomitmen untuk mengesahkan FCTC menjadi hukum atau kebijakan nasionalnya masing-masing, sehingga menjadi bagian dari negara-negara peserta (states parties) atas FCTC. Setiap negara diharapkan dapat menunjukkan komitmen yang kuat dalam mengurangi dampak penggunaan tembakau terhadap kesehatan, dengan langkah-langkah meratifikasi FCTC, menjabarkan lebih lanjut komitmennya ke dalam UU, serta kebijakan lainnya yang relevan. ${ }^{3}$

Di bawah bimbingan rezim kesehatan dunia, kelompok-kelompok anti tembakau tanpa disadari secara inheren juga anti kretek pemerintah RI didesak untuk [1] meratifikasi atau mengesahkan WHO FCTC menjadi Undang-Undang (UU), [2] merancang dan membahas RUU Pengendalian Tembaku, serta mengesahkan Rancangan Peraturan Pemerintah (RPP) Tembakau. Sampai akhir 2012, pemerintah dan DPR belum juga meratifikasi FCTC dan RUU Tembakau. Namun, mereka berhasil mengesahkan UU No. 36/2009 tentang Kesehatan, yang juga memerintahkan dibentuknya PP, dan akhirnya pemerintah mengesahkan PP No. 109/2012 tentang Pengamanan Bahan yang Mengandung Zat Adiktif berupa Produk Tembakau bagi Kesehatan. ${ }^{4}$

Persoalannya, judul PP itu berbeda dengan kandungan pasal-pasalnya, sehingga dapat dinyatakan bertentangan dengan Pasal 116 UU Kesehatan yang mengamanatkannya, atau bisa pula dipandang sebagai bentuk tipu muslihat. Karena kandungan pasal dalam PP itu lebih berkaitan dengan produk dan perdagangan produk tembakau, secara spesifik adalah produk industri rokok kretek, yaitu harga dan tarif cukai rokok, kemasan dan label produk, iklan, promosi dan sponsorship, serta mengontrol tujuan komersial dan kepentingan lain industri tembakau. Di satu sisi, sejumlah kandungan PP ini bersumber dari FCTC. Sama saja, keduanya bukan mengarahkan pada standarisasi produk untuk pengamanan bahan dan kandungan zat adiktif. Namun disisi lain, kran impor tembakau dan rokok putih meningkat. Maka, dengan "senjata" ini memperkuat dugaan bahwa pemerintah sedang mendesak ke belakang industri rokok kretek. ${ }^{5}$

Mengiringi kebijakan pengendalian tembakau yang kian ketat dalam empat tahun terakhir, bakal menimbulkan dampak buruk bagi para petani tembakau dan pengusaha pabrik rokok kecil. Dampak lebih jauh adalah lapisan buruh-tani tembakau dan pekerja pabrik rokok.

2 Wanda Hamilton, Nicotine War: Perang Nikotin dan Para Pedagang Obat, Yogyakarta: INSISTPress, 2010, hal. 43.

3 Roem Topatimasang, Puthut EA, dan Hasriadi Ary, (eds.), Kretek: Kajian Ekonomi dan Budaya 4 Kota, Yogyakarta: INSISTPress, 2010, hal. 140.

4 Ibid, hal. 145.

5 Komisi Nasional Hak Asasi Manusia, Naskah Akademik Rancangan Undang-Undang tentang Pengesahan Framework Convention on Tobacco Control (Konvensi Kerangka Kerja Pengendalian Tembakau), Jakarta: KomnasHAM, 2012, hal. 17. 
Rembesan persoalan ini menyangkut pula hajat hidup para pedagang tembakau dan produk tembakau. Sehingga cepat atau lambat mereka pun mengekspresikan berbagai bentuk resistensi terhadap setiap upaya yang merugikan dan menyumbat kepentingan petani tembakau dan industri pengolahan tembakau.

Para petani atau pengusaha tani pada umumnya berada dalam ikatan kerja bersama buruhtani dalam produksi tanaman tembakau, kemudian dipanen, diperam, dirajang, dijemur dan dibungkus. Mereka terlibat dalam produksi tembakau untuk kemudian dijual kepada pengusaha dagang dan pabrik rokok. Para petani sangat mengharapkan kestabilan dan peningkatan harga komoditas tembakau yang berefek pada tingkat upah buruh tembakau yang mereka pekerjakan. Sehingga dibutuhkan intervensi pemerintah dalam tata niaga untuk melindungi petani dari permainan harga. Namun, kebijakan pemerintah untuk mengendalikan konsumsi tembakau dan pengolahannya dipandang kurang melindungi petani tembakau dalam tata niaga serta kampanye anti rokok, telah menimbulkan serangkaian protes petani dan buruh tembakau.

Dampak yang dirasakan adanya resistensi ini ialah petani tembakau Kabupaten Temanggung. Mayoritas perkebunan tembakau ini terdapat di wilayah yang berada di lereng gunung api. Lokasilokasi tersebut sangat sesuai digunakan untuk perkebunan tembakau karena berada di dataran tinggi, lereng gunung di Temanggung yang menghadap ke arah timur sehingga mendapatkan penyinaran yang baik di pagi dan siang hari, unsur hara dalam tanah yang baik, serta suhu yang optimal sehingga sangat baik untuk tanaman tembakau. Hasil Produksi perkebunan tembakau merupakan salah satu sumber pemasukan terbesar di Temanggung. Wilayah Kecamatan Tlogomulyo merupakan wilayah yang terkenal akan kualitas tembakau terbaiknya. Tembakau jenis ini disebut sebagai Tembakau Srintil.

Tembakau srinthil merupakan tembakau berkualitas terbaik yang merupakan produk asli Indonesia yang dihasilkan daerah Temanggung. Bahkan jenis oleh tembakau tersebut sudah mendapat Sertifikat Indikasi Geografis dari Kementerian Hukum dan HAM. Tembakau srintil ini merupakan jenis tembakau dengan harga yang paling mahal. Wajar saja harga tembakau Srintil pun melangit. Sebagai ilustrasi pada 1976 harga tertinggi tembakau Temanggung mutu Srintil mencapai Rp.120.000,- per kg; pada 2009 harga Srintil mencapai Rp. 500.000,- hingga Rp. 750.000,- per kg; sementara tahun 2015 ini menembus angka Rp.1.250.000,- per kg. Bayangkan, tahun ini harga per kg Srintil senilai hampir dua gram harga emas. Tak berlebihan sekiranya tembakau sering disebut orang sebagai "emas hijau". 6 "Srinthil" merupakan tembakau grade F, G, H, dan I, dengan kadar nikotin yang paling tinggi, yakni sekitar 20\%. Setelah melalui riset dari Balai Penelitian Tanaman Tembakau dan Serat (Balittas) yang berkantor di Malang, Jawa Timur, diketahuilah bahwa ternyata kondisi alam, cuaca, dan struktur tanah di daerah Temanggung memang mampu memberikan panen tembakau dengan kualitas terbaik di dunia. ${ }^{7}$

6 Lihat Desa Tilir Kecamatan Tlogomulyo Kabupaten Temanggung,Tembakau Srintil Tlilir Tetap Jadi Primadona Desa, dalam tlilir-tlogomulyo.temanggungkab.go.id Pada: 17 Mei 2016 18:14:16 WIB, diakses 10 Februari 2018 pukul 13.00 WIB.

7 Lihat Cerita Indonesia Jalan Jalan Menikmati Negeri Pelangi, Srinthil, Tembakau Paling Mahal Ada Di Indonesia, dalam ceritaindonesia.web.id, April 42014 / Irwan Wahyu Tedjo, diakses pada 10 Februari 2018. 
Namun, Apresiasi pemerintah terhadap daun tembakau belakangan nampak setengah hati. Tekanan rezim kesehatan global yang mengatasnamakan isu kesehatan publik melalui skema FCTC justru mendorong terjadinya proses alih tanaman bagi petani tembakau. Mantan Gubernur Jawa Tengah, Bibit Waluyo pernah mendorong petani tembakau di sekitar lereng Sumbing dan Sindoro ini beralih menanam tanaman kopi. Menurutnya, tembakau tak lagi bisa diandalkan sebagai tanaman primadona yang menjanjikan keuntungan besar seperti dulu. "Ojo ngotot tetep nandur mbako,". ${ }^{8}$

Secara spesifik, kontrol pemerintah terhadap industri rokok kretek itu dikaitkan dengan dampaknya pada hak-hak ekonomi, sosial dan budaya, yaitu hak atas pekerjaan, hak atas upah dan tunjangan, hak atas jaminan sosial, dan hak untuk berpartisipasi dalam kebudayaan. Tujuannya adalah menunjukkan semakin terdesak ke belakang aspek tenaga kerja di saat negara memetik setoran pajak dan tarif cukai hasil tembakau yang terus meningkat. Dengan demikian, kajian dalam penulisan ini hendak membuka mata bahwa kretek telah mengaitkan kekhasan dan identitasnya dengan Indonesia. Sehingga tidaklah perlu mengarahkan dan menempatkan seakan-akan produk tembakau adalah produk "semi-ilegal". Sebaliknya, perlu dicari jalan yang lebih masuk akal ketimbang mempertentangkan secara berlebihan gara-gara paparan asap rokok berdampak pada kebutuhan kesehatan, pekerjaan, upah dan tunjangan serta bentuk-bentuk partisipasi dalam kebudyaaan. Menimbang betapa pentingnya bagi ekonomi dan budaya yang telah terbentuk ratusan tahun dan bersifat padat karya di Indonesia, khususnya hak-hak ekonomi, sosial dan budaya lainnya terkait upaya mengendalikan secara ketat terhadap tembakau dan produk pengolahan tembakau. Terlebih lagi, kampanye anti tembakau ini tidak diiringi dengan solusi ekonomi dan budaya yang dapat dipertanggungjawabkan.

\section{B. Bahan}

Menggunakan pendekatan hak-hak ekonomi, sosial dan budaya, maka dapat diperhatikan gerak kemunduran komitmen atau kewajiban pemerintah untuk memenuhi (obligation to fulfil) dan melindungi (obligation to protect) hak-hak itu. Pendekatan ini dilengkapi dengan metode deskriptif-analitis, sehingga dapat memberikan gambaran umum dan spesifik bagaimana hakhak yang dimaksud sedang berada dalam desakan lebih ke belakang di satu sisi, sementara di sisi lain dengan mengibarkan pentingnya kesehatan namun disusupi hambatan tarif (tariff barrier) dan hambatan non tarif (nontariff barrier) petani tembakau dihantam kebangkrutan.

\section{Hasil dan Pembahasan}

Langkah-langkah pengendalian tembakau itu telah didukung oleh penelitian tentang dampak konsumsi tembakau terhadap kesehatan yang dilakukan WHO, sehingga diperkirakan sampai tahun 2020 bakal menjadi persoalan kesehatan terbesar atas penyakit yang ditimbulkan. Diprediksi, praktik dan perilaku konsumsi tembakau dapat menyebabkan 8,4 juta kematian setiap tahun. Dikatakan, konsumsi tembakau bakal "membunuh" setiap orang dalam 10 detik. Diperkirakan pula bahwa peningkatan konsumsi tembakau di Asia dapat meningkatkan 
kematian empat kali lipat dari 1,1 juta orang (1990) menjadi 4,2 juta orang (2020).

Rezim kesehatan dunia memang telah memprioritaskan hak setiap orang untuk menjaga kesehatan berkaitan konsumsi tembakau dan paparan asap rokok, karena dinilai berisiko tinggi atas beberapa PTM, bahkan secara mengerikan dikampanyekan berisiko kematian. Tekanan ini diikuti oleh berbagai pihak di Indonesia untuk mengambil bagian dalam kampanye ini. Pemerintah telah lewat Presiden Yudhoyono akhirnya menandatangani Rancangan Peraturan Pemerintah (RPP) tentang Pengamanan Bahan yang Mengandung Zat Adiktif Berupa Produk Tembakau bagi Kesehatan menjadi PP No. 109/2012 pada pada 24 Desember 2012. Sebelumnya, Kementerian Koordinasi Bidang Kesejahteraan Rakyat Republik Indonesia (Kemenko Kesra) menyatakan, tujuan utama dari RPP adalah untuk memproteksi dan meningkatkan kesehatan generasi muda. ${ }^{10}$

Memang hal yang mengesankan terusung bahwa para perokok secara langsung telah membeli "tiket kematian dini". Padahal, ada banyak pengalaman lain yang konkret di mana sejumlah orang berusia senja laki-laki dan perempuan masih menikmati kepulan asap yang berasal dari racikan tembakau dan cengkehal. ${ }^{11}$ Bahkan, ada juga suatu penelitian yang menyimpulkan manfaat merokok, yaitu [a] menurunkan risiko operasi penggantian lutut, [b] menurunkan risiko penyakit parkinson, [c] menurunkan risiko obesitas, [d] menurunkan risiko kematian setelah si perokok mengalami beberapa serangan jantung, dan [e] membantu obat jantung clopidogrel bekerja lebih baik. ${ }^{12}$

\section{Pembahasan}

\section{Resistensi atas Pengendalian Tembakau}

Dalam perdagangan tembakau, pemerintah dikritik tidak peka terhadap kondisi petani. Di satu sisi kenijakan pemerintah dituding telah menghambat petani tembakau di dalam negeri, namun di sisi lain justru tidak pernah membatasi impor tembakau. Kebijakan seperti ini dipandang sebagai bentuk pengkhianatan terhadap perjuangan petani tembakau, karena dapat merusak harga tembakau nasional. ${ }^{13}$ Sementara tidak sedikit pula industri rokok nasional yang

9 Komisi Nasional Hak Asasi Manusia, Naskah Akademik Rancangan Undang-Undang tentang Pengesahan Framework Convention on Tobacco Control (Konvensi Kerangka Kerja Pengendalian Tembakau), Jakarta: Komnas HAM, 2012, hal. 17-18. Selain menyebabkan kematian bagi penggunanya, konsumsi rokok juga merugikan kesehatan orang lain. Asap rokok orang lain (AROL) dinyatakan, merugikan kesehatan orang lain karena mengandung asap dan partikel, terdiri 7.000 senyawa kimia dan partikel kecil yangmenjadi Particulate matter (PM2,5). Tahun 2010, Riskesdas mengungkapkan, sebanyak 62 juta perempuan dan 30 juta laki-laki menjadi perokok pasif, sehingga ada 92 juta perokok pasif.

10 Lihat Kompas, Kemenko Kesra: RPP Tembakau untuk Memproteksi Generasi Muda, Rabu, 4 Juli 2012, | 16:39 WIB, kompas.com, Diakses pada 16 Februari 2018 Pukul 13.00 WIB.

11 Roem Topatimasang, Puthut EA, dan Hasriadi Ary, (eds.), Kretek: Kajian Ekonomi dan Budaya 4 Kota, Yogyakarta: INSISTPress, 2010, hal. 167.

12 Penelitian dari Universitas Adelaide, Australia, muncul dalam jurnal Arthritis \& Rheumatism. Selain itu dalam dalam jurnal Thrombosis Research, edisi Oktober 2010. Lihat Tempo, Benarkah Merokok Ada Manfaatnya?, Jumat, 21 Desember 2012 | 07:00 WIB, tempo.com, Diakses pada 16 Februari 2018 Pukul 13.10 WIB.

13 Kritik ini dilontarkan Salamuddin Daeng, dengan memberikan catatan bahwa impor tembakau 2012 sekitar 100.000 ton atau meningkat sekitar 10 persen dari tahun sebelumnya. Sedangkan total produksi nasional 
menghadapi kekurangan bahan baku tembakau. ${ }^{14}$ Dengan disahkannya PP No. 109/2012 bakal berdampak naiknya impor tembakau sekitar 20 ribu ton yang menjadi 120 ribu ton. ${ }^{15}$

Para petani tembakau membutuhkan mekanisme tata niaga untuk melindungi mereka dari permainan para spekulan harga. Ketika harga tembakau anjlok pada 2004 harga tembakau basah jatuh sampai hanya Rp 500 per kilogram yang sebelumnya berkisar Rp 1.000 sampai Rp 12.000 per kilogram, banyak dikeluhkan para petani. Mereka pun mengekspresikan kekecewaan terhadap pemerintah yang tidak menciptakan tata niaga yang melindungi kepentingan petani. Pengalaman ini menimpa ratusan petani tembakau di berbagai Desa salah satunya Desa Legoksari, Kecamatan Tlogomulyo, Kabupaten Temanggung. Mereka menderita kerugian tanpa perlindungan oleh pemerintah dari para pemain pasokan tembakau untuk industri, sehingga mereka mengancam akan melakukan protes.

Bentuk protes yang dilakukan petani dan buruh tani diantaranya; pertama, pada Juli 2011, sekitar 3.000 petani dan buruh tembakau dari Kabupaten Temanggung, berasal dari 14 kecamatan dengan menumpang 59 bus berangkat ke Jakarta untuk berunjuk rasa menolak RPP Tembakau. Sejumlah perempuan petani tembakau sudah berangkat lebih dulu menggelar aksi mogok makan di Jakarta. Rombongan petani dan buruh tembakau ini juga membawa grup kesenian dari Kecamatan Kledung dan Bulu. Kelompok kesenian ini nantinya akan dipentaskan untuk memberi semangat peserta aksi. APTI menyatakan, bakal melakukan beberapa aksi lagi, antara lain tidak akan membayar pajak dan tidak menggunakan hak pilih dalam pemilu bila RPP disahkan. ${ }^{16}$

Kedua, pada November 2011, APTI Jawa Tengah mengancam akan memblokade jalan akses di desa-desa yang menjadi sentra-sentra tembakau bermutu tinggi. RPP Tembakau mereka pandang sebagai upaya mengganggu kehidupan mereka, sehingga mereka menentangnya. ${ }^{17}$ Ancaman APTI bukanlah isapan jempol belaka, karena para petani dan buruh tembakau kembali menggelar unjuk rasa pada Desember 2011. Ribuan petani tembakau di Keresidenan Kedu, Temanggung, Magelang, Wonosobo, Kebumen, dan Purworejo menggelar aksi unjuk rasa menolak RPP Tembakau. Mereka memblokade jalur utama dari Temanggung menuju

sebesar 180.000 ton. Lihat Kompas, Petani Tembakau Dihambat, Impor Tak Dihalangi, bisniskeuangan.kompas. com, Kamis, 10 Januari 2013 | 14:27 WIB, Diakses pada 17 Februari 2018 Pukul 13.00 WIB.

14 Lihat Kontan, Pabrik Rokok Kurang Pasokan Tembakau, industri.kontan.co.id, Minggu, 03 April 2011| 13:22 WIB, Diakses pada 17 Februari 2018 Pukul 13.05 WIB. Gabungan Produsen Rokok Putih Indonesia (Gaprindo) mengungkapkan, kebutuhan tembakau industri rokok mencapai 240.000 ton per tahun atau ekuivalen dengan produksi rokok sebanyak 230 - 240 miliar batang per tahun. Sementara produksi tembakau nasional hanya mampu menyuplai tembakau sekitar 150.000 ton hingga 180.000 ton.

15 Lihat Liputan6, PP Tembakau Bikin Impor Tembakau Naik 20 Ribu Ton, bisnis.liputan6.com, Selasa, 05 Februari 2013| 19:31 WIB, Diakses pada 17 Februari 2018 Pukul 13.15 WIB. APTI mengungkapkan, impor tembakau dalam beberapa tahun terakhir selalu melonjak. Pada 2003, volume impor tembakau hanya 23 ribu ton. Kemudian impor di 2011 naik menjadi 91 ribu ton. Pada 2012 impor tembakau menembus 100 ribu ton dan dikhawatirkan tahun ini impor tembakau bisa 120 ribu ton.

16 Lihat Antara, Ribuan Petani Tembakau Temanggung Demo ke Jakarta, antaranews.com, Selasa, 12 Juli 2011 |18:37 WIB, Diakses pada 17 Februari 2018 Pukul 14.00 WIB.

17 Lihat Kompas, Petani Tembakau Ancam Blokade Jalan, kompas.com, Selasa, 8 November 2011 | 12:44 WIB. Diakses pada 17 Februari 2018 Pukul 14.10 WIB. 
Wonosobo, tepatnya di Tugu Galih, Pasar Paraan, Temanggung. Sebelum orasi dilakukan, massa telah melakukan pembakaran ban dengan cara menyiram bensin kemudian menyulutnya dengan api. Massa meneriakkan yel-yel penolakan RPP, seperti “Tolak RPP sekarang juga!”Spanduk juga dibentangkan, "Kretek simbol kedaulatan bangsa, RPP Tembakau = PHK massal buruh kretek, tolak!". ${ }^{18}$ Pada 22 Desember, juga berlangsung demo turun ke jalan yang diikuti ribuan petani dan buruh tembakau yang tergabung dalam KNKP Jateng di Kendal, Magelang, Kudus, dan Boyolali, selain di Temanggung. ${ }^{19}$

Ketiga, pada Juli 2012, APTI Temanggung mengerahkan ribuan petani dan buruh tembakau di Kabupaten nya untuk bergabung dengan petani dan buruh dari Wonosobo, Kendal, Boyolali, Jawa Timur, dan Jawa Barat di Jakarta untuk melakukan demonstrasi menolak rencana pengesahan RPP Tembakau. Mereka berangkat dengan menggunakan sekitar 100 bus dari Jawa Tengah untuk mengangkut massa ke Jakarta. Masing-masing dari mereka rela mengeluarkan uang Rp 200.000 per orang, sedangkan mereka yang tidak bisa ikut demo ke Jakarta, bersedia membantu secara suka rela Rp 50.000 per orang. ${ }^{20}$ Mereka yang tergabung dalam Koalisi Nasional Penyelamatan Kretek (KNKP) dan APTI belum puas dengan berdemonstrasi di Kemenkes dan Kemenko Kesra, sehingga menyambangi juga Gedung DPR untuk meminta audiensi. ${ }^{21}$

Keempat, 15.000 petani dan buruh tembakau dari lereng Sindoro yang melakukan aksi serupa di lapangan Desa Bansari, Kecamatan Bansari, Kabupaten Temanggung, pada 19 Februari 2013. Para demonstran ini juga mengarak keranda, keranjang tembakau, serta mengusung berbagai spanduk antara lain bertuliskan, "Tembakau Nafas Kami Nyawa Kami” dan "Tembakau Atau Mati!”. Ketua MUI Temanggung ikut ambil bagian dalam aksi ini serta memberikan tausiyah keagamaan untuk menyabarkan demonstran yang sempat memanas. ${ }^{22}$

Kelima, para petani dan buruh tembakau di lereng Gunung Sindoro, Kabupaten Temanggung, memprotes atau mengecam fatwa haram merokok yang dikeluarkan PP Muhammadiyahal. Ekspresi protes mereka berunjuk rasa dengan melakukan teatrikal membakar tembakau di atas telapak tangan dan di atas kepala mereka. Kendati kesakitan menahan panas, namun mereka tetap melakukannya. Sejumlah petani bahkan memenuhi mulut mereka dengan batang-batang rokok yang menyala, kemudian dihisap layaknya orang merokok. Mereka khawatir fatwa ini dapat mematikan sumber atau kelangsungan usaha mereka. ${ }^{23}$

18 Lihat Detik, Ribuan Petani Demo di Temanggung, Tolak RPP Tembakau, detik.com, Kamis, 22 Desember 2011 |11:03WIB, Diakses pada 17 Februari 2018 Pukul 14.15 WIB. RPP Tembakau ini mengatur larangan penayangan iklan rokok, sponsor acara, kegiatan CSR, larangan penjualan rokok secara eceran, dan pada orang di bawah 18 tahun serta wanita hamil.

19 Lihat Kompas, Ribuan Petani Tembakau Jateng Turun ke Jalan, kompas.com, Kamis, 22 Desember 2011 | 07:24 WIB, Diakses pada 17 Februari 2018 Pukul 14.45 WIB.

20 Lihat Bisnis Jateng, Petani tembakau Temanggung menuju Jakarta, bisnis-jateng.com, Senin, 2 Juli 2012, Diakses pada 17 Februari 2018 Pukul 16.15 WIB.

21 Lihat Suara Merdeka, Petani Tembakau Jateng Sambangi DPR, suaramerdeka.com, Rabu, 04 Juli 2012 18:46 WIB, Diakses pada 17 Februari 2018 Pukul 16.30 WIB.

22 Lihat Suara Merdeka, 15 Ribu Petani Tembakau Gunung Sindoro Demo Tolak PP 109, suaramerdeka.com, Rabu, 20 Februari 2013 | 01:45 WIB, Diakses pada 17 Februari 2018 Pukul 17.15 WIB.

23 Lihat Liputan 6, Petani Tembakau Protes Fatwa Haram Rokok, liputan6.com, Jumat, 12 Maret 2010 | 14:08 WIB, Diakses pada 17 Februari 2018 Pukul 17.30 WIB. 
Banyak lapisan petani dan buruh tembakau, telah mengekspresikan penolakan mereka terhadap pengendalian tembakau secara lebih ketat dan mereka pandang dapat mengganggu kepentingan mereka. Petani dan buruh tembakau memperkirakan dampak PP Tembakau terhadap konsumsi rokok, yakni bakal menurun atau berkurang. Karena banyak aturan seperti aturan produksi, konsumsi rokok, promosi produk (iklan) dan banyak lagi yang dibatasi dan dikendalikan oleh pemerintahal. Ditambah lagi dengan kebijakan Kawasan TanpaRokok (KTR) yang juga dapat mengurangi konsumsi rokok. PP Tembakau sudah mengancam kelangsungan pekerja.

\section{Srinthil Sebagai Warisan Budaya Berkontribusi Atas Hak-Hak EKOSOB}

Tanaman tembakau (Nicotiana tabacum) adalah genus tanaman yang berdaun lebar yang semula berasal dari Amerika. ${ }^{24}$ Selain digunakan sebagai bahan baku dalam industri rokok, tembakau dapat pula menghasilkan protein anti-kanker "Growth Colony Stimulating Factor" (GCSF) yang berguna bagi penderita kanker. Kegunaan lainnya adalah untuk menstimulasi perbanyakan sel tunas (stemcell) yang bisa dikembangkan untuk memulihkan jaringan fungsi tubuh yang sudah rusak. ${ }^{25}$ Tembakau yang dimodifikasi secara genetik dapat memproduksi obat diabetes dan kekebalan tubuhal. Tembakau transgenik yang memproduksi interleukin-10 (IL10) merupakan cytokine antiradang yang ampuhal. Cytokine adalah protein yang merangsang sel-sel kekebalan tubuh agar aktif. Penggunaan IL-10 dalam dosis kecil dapat membantu mencegah kencing manis (diabetes mellitus) tipe $1 .{ }^{26}$ Beberapa lainnya manfaat tembakau adalah melepaskan gigitan lintah, obat HIV/AIDS, dan obat luka. ${ }^{27}$

Seiring dengan disahkannya Peraturan Pemerintah No. 109/2012 tentang Pengamanan Bahan yang Mengandung Zat Adiktif Berupa Produk Tembakau bagi Kesehatan, pada 24 Desember 2012, diberlakukan mulai tahun 2014. PP ini mewajibkan pabrik rokok putih untuk membungkus 20 batang rokok dalam satu bungkus, sehingga tidak ada lagi kemasan 12 atau 16 batang. Rokok juga dilarang menjual atau memberi kepada anak berusia di bawah 18 tahun dan perempuan hamil. Pada samping kemasan produk, harus pula tercantum pernyataan, "Tidak ada batas aman" dan "Mengandung lebih dari 4.000 zat kimia berbahaya serta lebih dari 43 zat penyebab kanker". ${ }^{28}$

24 Contohnya, tembakau Virginia. Virginia adalah salah satu negara bagian di Republik Amerika Serikat (United State of America, USA) yang terletak di sebelah timur. Jenis tembakau ini banyak terdapat di Lombok.

25 Peneliti dari Pusat Penelitian Bioteknologi Lembaga Ilmu Pengetahuan Indonesia (LIPI), Dr Arief Budi Witarto M.Eng adalah seorang ahli di bidang rekayasa protein. Dia menjelaskan, tanaman tembakau dapat dimanfaatkan sebagai reaktor penghasil protein GCSF, suatu hormon yang menstimulasi produksi darahal. Lihat Antara, Tembakau Dapat Hasilkan Protein Anti-Kanker, antaranews.com, Kamis, 14 Juni 2007 | 00:47 WIB, Diakses pada 17 Februari 2018 Pukul 19.30 WIB.

26 Lihat Gatra, Tembakau untuk Obat Kencing Manis, gatra.com, Kamis, 16 April 2009, Diakses pada 17 Februari 2018 Pukul 20.00 WIB. Menurut Profesor Mario Pezzotti dari Universitas Verona, tanaman transgenik menarik untuk sistem produksi protein kesehatan karena menawarkan kemungkinan produksi pada skala besar dengan biaya rendah, sehingga menghindari proses pemurnian yang panjang dibandingkan dengan obat tradisional sintetis.

27 Lihat, Budiah Sari Siregar, Tembakau Manfaat yang Terlupakan, analisadaily.com, Senin, 06 Agustus 2012 | 00:04 WIB, Diakses pada 17 Februari 2018 Pukul 20.10 WIB.

28 Lihat Viva, PP Tembakau Disahkan, Apa yang Dilarang?, viva.co.id, Rabu, 9 Januari 2013|10:53WIB, 
Karena tidak adanya larangan menanam maupun memperdagangkan tembakau, maka tembakau bukanlah komoditas ilegal. Memproduksi dan mendistribusi tembakau bukanlah suatu tindakan ilegal, melainkan sesuatu yang diperbolehkan. Setiap orang bebas memproduksi dan mendistribusi tembakau sebagai komoditas baik diperdagangkan di pasar dalam negeri maupun diekspor ke negeri lain. Karena tembakau bukan termasuk narkotika yang dilarang berdasarkan hukum atau UU.

Tembakau yang ditanam di lereng gunung Sindoro dan Sumbing, Kabupaten Temanggung, sebagian adalah penghasil tembakau kualitas nomor satu, yakni tembakau srinthil. Kendati ditanam dan dipanen dari kebun yang sama, tidak semua tembakau "dianugerahi” sebutan srinthil, yang bisa dijual dalam kisaran Rp 400.000 - Rp 800.000 per kilogram. Seorang petani tembakau di Dukuh berpegang pada warisan pengetahuannya tentang tembakau secara turuntemurun, yaitu tanah (sithi), benih (wiji), dan cuaca atau waktu (wanci). Contoh tanahnya pernah diperiksa di Institut Pertanian Bogor (IPB) dan dibawa ke Amerika Serikat (AS) untuk mengetahui apakah contoh tanah ini dapat menghasilkan kualitas tembakau yang terbaik. Selain itu, kualitas tembakau bergantung juga kepada cuaca atau waktu. Misalnya, ketika tanaman membutuhkan guyuran hujan, namun hujan tidak turun, atau sebaliknya, dapat menimbulkan stress atau ketebalan daunnya mengempes. ${ }^{29}$

Penanaman tembakau telah berlangsung secara turun-temurun, dengan pengetahuan yang diwariskan dari satu generasi ke generasi berikutnya. Dengan jenis tanah yang berbeda, hasil tembakau juga berbeda. Oleh karennya di Temanggung termasyhur sebagai penghasil srinthil. Tembakau Srinthil telah terdaftar sebagai Indikasi Geografis No. ID G 000000027 di Direktorat Jenderal Kekayaan Intelektual. ${ }^{30}$ Terdaftarnya Srinthil berarti Pemerintah mengakui bahwa ada keunikan tersendiri pada tembakau Srinthil yang terikat pada Desa Legoksari, Kecamatan Tlogomulyo, Kabupaten Temanggung. Keunikan ini terikat pada daerah tempat tembakau tersebut ditanam.

Indikasi Geografis ini akan membakukan karakteristik tembakau Srinthil, tercatat di Direktorat Jenderal Kekayaan Intelektual. Indikasi Geografis tidak bersifat individu, namun dimiliki oleh masyarakat, komunal, yang dalam hal Tembakau Srinthil dimiliki oleh Masyarakat Perlindungan Indikasi Geografis-Tembakau Srinthil Temanggung (MPIG-TST). Selain Indikasi Geografis srinthil berkembang bersama dengan tradisi warga sebagai budaya turun temurun dari leluhur. Warga Legoksari memiliki ritual-ritual yang dilakukan sepanjang musim tembakau. Ritual ini merupakan wujud penghormatan kepada Dewi Sri yang telah memberikan keberkahan kepada warga Desa sehingga mendapatkan hasil berupa tembakau srinthil dengan mutu terbaik.

Macam-macam ritual yang diadakan diantaranya ${ }^{31}$, pertama; nyecell lekas macul, ritual ini Diakses pada 17 Februari 2018 Pukul 20.20 WIB.

29 Puthut E.A, Hikayat Negeri Tembakau, National Geographic Indonesia, Desember 2012, hal. 44 - 45. Sedikitnya 14 dari 19 kecamatan di Temanggung, adalah sentra penghasil tembakau, dengan luas lahan sekitar 15.000 hektare. Perputaran uang ketika panen tembakau, bisa lebih dari Rp 1 triliun.

30 Direktorat Jendral kekayaan Intelektual Kementrian Hukum dan Hak Asasi Manusia R.I., Indikasi Geografis Terdaftar, Direktorat Jenderal Kekayaan Intelektual - Kementerian Hukum dan HAM R.I., 2018, hal.5.

31 Elva Laily, Srinthil Pusaka Saujana Lereng Sumbing, Yogyakarta: Pustaka Indonesia, 2016, hal. 163-194. 
diawali dengan membakar kemenyan yang dijepit bilah diatas bara api. Nyecel dilakukan petani untuk mengawali pencangkulan tanah pada saat mengolah lahan. Ritual ini diadakan di kebun tembakau dan petani membawa sesaji berupa tumpeng cambah pethek.

Kedua; lekas nandur/nglekasi merupakan bentuk ritual yang diadakan di kebun tembaku sebagai pertanda petani akan memulai menanam tembakau. Biasanya ritual lekas nandur diadakan sebulan sebelum penanaman. Sesaji dalam ritual ini sama dengan nyecel, yaitu tumpeng cambah pethek. Ketiga; miwitillekas petik merupakan ritual untuk mengawali pemetikan tembakau. Miwiti dilakukan di kebun tembakau dan pelaksanaannya tidak boleh bertepatan dengan sangar tahun (hari pertama permulaan tahun Jawa yang jatuh pada Rebo Wage berdasar penanggalan Aboge serta hari naas). Isi sesaji dalam ritual ini adalah tumpeng cambah pethek, beras kapuroto, gula kelapa, biji-bijian, telur rebus dan kemenyan berlangsung di kebun tembakau sifatnya perorangan.

Keempat; tungguk merupakan ritual yang dilakukan saat pertengahan petik tembakau. Unsur sesaji dalam tungguk hampir sama dengan miwiti hanya saja ada beberapa tambahan seperti ingkung, jadah pasar, tembakau, ketan, salak, daun sirih, candu, uang dan bunga wangi. Ritual ini dilakukan pada saat odeg, tenggok atau mrothol. Kelima; kepung jenang candil, ritual dilakukan memulai proses rajang tembakau. Dimaksudkan sebagai wujud penghormatan kepada Saudagar Dayang Awang yang dipercaya sebagai pembeli pertama tembakau srinthil untuk dijual ke Kudus. Selain itu menghormati belas kleas (penunggu gobang). Ritual dilakukan dengan harapan yang akan dirajang bisa nyrinthil seperti olahan ketan. Ritual dilakukan malam hari setelah pagi harinya petani habis memetik daun tembakau dan memeramnya. Sesaji dalam ritual ini jenang candil wedang santen.

Keenam; merti Desa/besaran merupakan slametan dengan rangkaian prosesi ritual yang panjang dengan melibatkan seluruh warga Desa Legoksari. Ritual ini diadakan untuk menghormati Kyai Gliding dan mensyukuri keberkahan serta keselamatan selama satu tahun bertani tembakau. Ritual diadakan setahun sekali dibulan besar (Dzulhijah) sebelum menyambut tahun baru Islam Suro (Muharram). Sesaji ritual ini berisi tumpeng putih, ingkung ayam, jadah pasar, lanyahan, 5 jenis wedang.

Ketujuh; nyukuri kali, ritual ini dilaksanakan setelah panen tembakau oleh warga secara berkelompok mencari mata air dengan cara membersihkan dan perawatan sumber air. Nyukuri kali merupakan serangkaian ritual diawali dengan pembacaan doa, pembakaran kemenyan dan sesaji terdiri dari tumpeng cambah pethek, jajanan pasar, ingkung ayam, tumpeng, kacang kapri, telur ayam kampung dan jenang blohok. Kedelapan; numbali Desa, diantara semua ritual dan tradisi yang hidup serta melekat dalam keseharian para petani tembakau Legoksari, numbali Desa adalah ritual yang paling jarang dilakukan. Pelaksanaan ritual hanya sewindu malam Jum'at Kliwon dengan harapan menghindari pagebluk (bencana), penyakit mematikan serta duratmaka. Sesaji utama proses ini adalah wedhus kendhit.

Berbagai ritual warisan leluhur membawa dampak pada mutu dan kualitas yang memunculkan keragaman tembakau yang dihasilkan secara tidak langsung mampu merubah 
ekonomi masyarakat melalui harga tembakau. Harga tembakau srinthil terlihat dari macam yang dihasilkan, satu sama lain memiliki harga yang berbeda. Tembakau srinthil yang dihasilkan diantaranya $^{32}$ (1) Srinthil ajer adalah tembakau berwarna hitam pekat dengan daun dan batang daun ajer (lumer) saat pemeraman sehingga seratnya hampir tidak terlihat. Tembakau srinthil jenis ini beraroma legi dengan mutu I. (2) Srinthil ngelar kumbang adalah tembakau srinthil dengan warna hitam memantulkan sinar kebiruan (menyerupai warna biru pada bulu kumbang) jika terkena cahaya. Tembakau srinthil jenis ini beraroma buah salak dan nangka dengan mutu Hal. (3) Srinthil nyambel iler dipakai untuk menyebut tembakau srinthil yang memiliki warna hitam pekat seperti aspal. Tembakau dengan ciri ini memiliki nikotin sampai 6,97\%, serat tersisa pada tembakau srinthil jenis ini sekitar 10\%. Tembakau ini memiliki aroma kesegaran gondo jero dengan mutu G. (4) Srinthil nawon madu merupakan tembakau srinthil yang warnanya menyerupai warna perut lebah madu. Serat tembakaunya berwarna jingga kehitaman atau kuning kemerahan. Ada juga menyebut srinthil abang dan srinthil mbrambang. Tembakau srinthil jenis ini merupakan tembakau srinthil dengan mutu yang bagus dengan kandungan serat 30\% dan memiliki aroma menyengat seperti bunga melati dengan mutu F/E.

Tembakau termasuk salah satu komoditas hasil pertanian yang penting. Kualitas tinggi tembakau srinthil telah menempatkannya sebagai sebutan "emas hijau", karena harganya bisa mencapai ratusan ribu rupiah per kilogram. Melihat potensi srinthil menjadikan keadaan sosial masyarakat desa Legoksari terbilang ketercukupan dengan melihat harga jual tembakau dari tahun ke tahun. ${ }^{33}$ Apalagi tembakau memiliki arti penting bagi kehidupan masyarakat dan pembangunan Desa. Hasil panen tembakau tidak semua dimanfaatkan memenuhi kebutuhan sehari-hari, melaikan disisihkan manjadi uang jimpitan. Uang jimpitan diserahkan setiap panen tembakau sebesar 2,5\% sebagai penggerak perekonomian Desa sejak tahun1970. Saat gagal panen tembakau petani tetap memiliki kemampuan mengumpulkan uang jimpitan. Potret kehidupan ini lah menjadikan Desa Legoksari kental dengan kearifan lokal mengenai tembakau secara turun temurun dari generasi I hingga sampai saat ini sudah ada gerasi IV petani srinthil.

\section{Dampak Pengendalian Tembakau Di Kalangan Masyarakat Srinthil}

Kretek terbaik produksi Indonesia tak sah jika tak mengandung tembakau 'srinthil dari Temanggung. Tak heran Mark Hanusz, penulis buku Kretek: The Culture and Heritage of Indonesia's Clove Cigarette, menjuluki Temanggung sebagai 'Vuelta Abajo' nya Indonesia'. Tembakau Temanggung, terutama jenis srinthil, telah menjadi bagian jati diri (identitas) tersendiri daerah ini. Ketenarannya bahkan telah melanglangbuana sampai ke mancanegara. Bahkan, para connoisseur (pakar cita-rasa tembakau) di kota Bremen, pusat lelang tembakau dunia, lebih mengenal Temanggung daripada Jakarta. Atau, paling tidak, sama terkenalnya

32 Elva Laily, Srinthil Pusaka Saujana Lereng Sumbing, Yogyakarta: Pustaka Indonesia, 2016, hal. 46-91.

33 Tahun 1979-1980an srinthil ilerlajer harga Rp 75.000, 1997 srinthil nyambel iler harga Rp 110.000, 2006 srinthil nyambel iler harga Rp 500.000, 2007 srinthil nyambel iler harga Rp 600.000, 2008 srinthil abang harga Rp 450.000, 2009 srinthil ajer harga Rp 600.000, 2013 srinthil abang harga Rp 250.000, 2014 srinthil nyambel iler harga Rp 350.000, 2015 srinthil nawon madu harga Rp 1.250.000. Elva Laily, Srinthil Pusaka Saujana Lereng Sumbing, Yogyakarta: Pustaka Indonesia, 2016, hal. 198. 
dengan Bali. ${ }^{34}$

Tetapi dibalik kesuksesan tembakau sebagai salah satu komoditas yang memiliki sumbangsih besar terhadap penerimaan negara, pemerintah justru mengeluarkan beberapa kebijakan yang menentang terhadap perkembangan pemasaran tembakau khususnya rokok. Terdapat beberapa kebijakan pemerintah yang dinilai menentang terhadap perkembangan produk-produk tembakau dikalangan masyarakat, antara lain: (1) Peraturan Pemerintah Nomor 109 Tahun 2012 tentang Pengaman Bahan yang Mengandung Zat Adiktif Berupa Produk Tembakau Bagi Kesehatan; (2) Peraturan Bersama Menteri Dalam Negeri NOMOR 188/MENKES/PB/I/2011 tentang Pedoman Pelaksanaan Kawasan Tanpa Rokok (KTR). Hal tersebut tentunya memberikan dampak terhadap tren perkembangan industri rokok. Kemudian, kebijakan tersebut juga memberikan dampak tidak langsung (indirect effect) terhadap petani tembakau.

Menurunnya jumlah industri rokok diyakini akan berdampak terhadap permintaan tembakau di pasar. Ketidakseimbangan antara permintaan dengan jumlah produksi tembakau ditingkat petani diyakini dapat berpengaruh terhadap harga tembakau. Sehingga dampak inilah yang menjadi pemicu ketidakstabilan harga ditingkat petani. Struktur pasar tembakau berbentuk oligopsoni, dimana penentuan harga sepenuhnya dikuasai oleh pedagang pengumpul. Sementara itu pedagang besar yang menguasai pembelian dari pedagang pengepul dan menjualnya ke pihak pabrikan rokok. kondisi ini juga dinilai sebagai pemicu ketidakstabilan harga tembakau ditingkat petani. Tidak jarang pihak pengepul atau juragan memainkan harga tembakau guna memaksimalkan keuntungan sendiri tanpa memperhitungkan kerugian yang harus ditanggung oleh petani. Besaran biaya yang harus dikeluarkan petani saat proses produksi sampai panen cukup tinggi, kondisi tersebut tidak diimbangi dengan total penerimaan petani saat musim panen. Kondisi tersebut mengakibatkan pendapatan diterima petani setiap tahunnya menjadi semakin tidak stabil. ${ }^{35}$

Dalam sumber daya produksi inilah para petani dan buruh tani tembakau bekerja menggarap aktivitas produksi menunjukkan banyaknya orang menggantungkan hidupnya menggarap perkebunan tembakau. Demikian pula mereka yang menjadi buruh-tani tembakau. Pengolahan tembakau ini menjadi perintis dan peletak dasar-dasar industri kretek, dari tanaman tembakau dan cengkeh diolah menjadi rokok kretek di Kudus. Temanggung tertancap dua gunung yang terkait dengan tembakau, yaitu Gunung Sindoro dan Gunung Sumbing. Pada kaki kedua gunung ini tersemai hamparan tanaman tembakau jenis srinthil di lereng-lereng gunung itu yang menjadi buah bibir dunia pertembakauan diibaratkan sebagai tambang "emas hijau” dengan perputaran uang terbesar dan sebagian tembakau dari Jawa Tengah diekspor. Temanggung memang "Kabupaten tembakau" dengan jumlah petani terbanyak, yakni 49.528 orang. ${ }^{36}$

34 Mark Hanusz, Kretek: The Culture and Heritage of Indonesia's Clove Cigarette, Jakarta: Equinox, 2000, hal. 80.

35 Ambariyanto dan Herawati N, Pengembangan Kelembagaan Pemasaran Komoditas Tembakau terhadap Kesejahteraan Petani di Kabupaten Sumenep, Jurnal Akuntansi, Manajemen Bisnis dan Sektor Publik, 2010, hal. $21-45$.

36 Wisnu Brata, Tembakau atau Mati: Kesaksian, Kegelisahan, dan Harapan Seorang Petani Tembakau. Jakarta: Indonesia Berdikari, 2012, hal. 76. 
Bagi para petani, tembakau memang tak sekedar komoditi. Tembakau menjadi bagian penting dari kehidupan spiritual. Unsur tembakau berupa rajang, kretek atau rokok dalam sesaji yang melambangkan api, air, udara dan tanahal. Dengan demikian tembakau dianggap sebagai penyeimbang antara manusia dan alam. Para petani di Desa Legoksari hampir semua ladangnya ditanami oleh tembakau berkualitas tinggi. Namun dengan bergulirnya RPP Tembakau telah memicu anjloknya harga tembakau itu sekitar 50\% dari harga awal. Anjloknya harga tembakau ini merugikan para petani yang menggantungkan penghasilannya dari menanam tembakau. Petani menilai PP Tembakau tidak mengakomodasi kepentingan petani, karena tidak satu pasal pun yang dapat menunjukkannya. ${ }^{37}$

Para petani di Legoksari Kabupaten Temanggung juga merugi seiring anjloknya harga tembakau. Harga tembakau yang dipanen tahun 2012 jatuh drastis. Tembakau kualitas grade F hanya laku sekitar Rp 80.000 per kilogram, padahal sebelumnya bisa berharga Rp 300.000 per kilogram. Beberapa petani mengatakan, tembakau rajangan milik mereka dengan kualitas grade D masih menumpuk di rumah, karena harganya rendah dan belum mau menjualnya. Sebelumnya harga grade D Rp 60.000 - Rp70.000 per kilogram, namun beberapa hari sesudah gudang kembali dibuka, harganya turun menjadi Rp 40.000 - Rp 50.000 per kilogram. ${ }^{38}$

Sebaliknya, kebijakan pemerintah semakin memperbesar keuntungan produksi tembakau impor tanpa pembatasan yang sekaligus menunjukkan pengingkarannya terhadap aspek kesehatan dimana tembakau dinyatakan sebagai barang adiktif. Berdasarkan data Badan Pusat Statistik (BPS) November 2012, impor tembakau sudah mencapai 120 ribu ton. Jumlah ini sudah melampaui separuh lebih dari kebutuhan tembakau nasional mencapai 200 ribu ton. Impor ini bakal mempersulit petani tembakau lokal. Dengan jumlah impor yang semakin bertambah atau kebijakan impor semakin longgar, maka bisa dinilai kelakuan pemerintah dalam menempatkan PP Tembakau, sudah berubah: tembakau dari barang adiktif bergerak menjadi "non-adiktif". 39

Bila harga-harga tembakau tidak dapat dipulihkan untuk mempertahankan tingkat kesejahteraan petani terutama biaya produksi, maka dapat dipastikan ujung dari kebijakan pemerintah bakal mengulangi petaka yang mendera gula dan beras di masa lalu. Para petani tembakau di Temanggung menunjukkan tekad mereka untuk tidak pernah meninggalkan tembakau. Menanam tembakau adalah lahan penghasilan mereka untuk mendapatkan makanan, menyekolahkan anak-anak dan menghidupi keluarga sampai bisa naik haji. Mereka menyatakan tetap kompak dalam satu bahasa untuk mempertahankan tembakau, tidak bersedia melakukan konversi tanaman tembakau. Karena belum ditemukan tanaman konversi tembakau yang setidaknya menghasilkan keuntungan yang sama dengan tembakau, terutama di lahanlahan yang hanya mungkin tanaman tembakau tumbuhal. Sejumlah lahan tembakau yang telah diujicobakan dan diganti dengan tanaman lain di beberapa daerah di Madura, berakhir dengan kenyataan: selalu gagal.

37 Sri Margana, Kretek Indonesia:Dari Nasionalisme Hingga Warisan Budaya. Yogyakarta: Puskindo, 2014, hal. 45. 38 Ibid., hal. 50.

39 Syamsul Hadi, dkk., Kudeta Putih: Reformasi dan Pelembagaan Kepentingan Asing dalam Ekonomi Indonesia. Jakarta: Indonesia Berdikari, 2012, hal. 56. 
Pengaruh wacana kesehatan global yang dikampanyekan kelompok anti tembakau telah menyusup dalam regulasi di negara Indonesia. Kebijakan pengaturan tembakau lebih mengutamakan aspek kesehatan dari pada aspek ekonomi, sosial, dan budaya. Kebijakan ini justru melemahkan petani. PP ini dibuat seolah tidak melarang atau membatasi tembakau, seolah-olah tidak ada kaitannya dengan petani tembakau, cengkeh, buruh, tenaga periklanan dan tenaga kerja langsung maupun tak langsung. Padahal secara logika jika industri kretek nasional dimatikan maka petani, buruh dan tenaga kerja langsung maupun tidak langsung akan terkena imbasnya. Kebijakan pengaturan tembakau yang didorong oleh Kementerian Kesehatan selama ini dengan memposisikan tembakau dan produk turunannya sebagai wabah (epidemi) penyakit yang harus diberantas sampai tuntas. Rokok dipersamakan dengan barang ilegal yang bahkan menimbulkan dampak lebih buruk dari narkoba karenanya harus dikucilkan. Seakanakan tidak ada persoalan kesehatan yang lebih penting dari sekadar perang anti tembakau.

Cara melihat persoalan tembakau dari sudut pandang kesehatan dengan meniadakan perspektif lainnya ini bukan hanya tidak tepat melainkan justru menyesatkan. Alasannya, tembakau adalah barang legal dan komoditi unggulan yang mempunyai peran vital dengan pertautan kepentingan ekonomi, sosial dan budaya. Pemaksaan perspektif kesehatan secara terus-menerus melalui kampanye serta mengukuhkannya dalam bentuk regulasi berpeluang membawa persoalan tembakau menjadi masalah sosial yang lebih besar. Ambruknya industri kretek akan mengakibatkan jutaan petani tembakau, cengkeh dan buruh kehilangan pekerjaan dan negara tak mempunyai sumber pendapatan besar untuk pembangunan.

Dengan demikian pemerintah belum bisa menjadi mengakomodir hak-hak manusia (human rights) tidak hanya hak-hak sipil dan politik, namun juga hak-hak ekonomi, sosial dan budaya. Hak-hak manusia merupakan suatu klaim yang berdasar, sah (legitim) bagi setiap orang baik berdasarkan moral atau kesepakatan, ataupun perjanjian dan hukum. ${ }^{40}$ Hak-hak ini saling bergantung (interdependent) dan tidak terpisahkan (indivisible) satu sama lain. Dalam konsep dan norma hak-hak manusia, dikenal istilah kewajiban negara (obligation of the state). Secara umum, kewajiban negara ada tiga, yaitu kewajiban menghormati (obligation to respect), kewajiban melindungi (obligation to protect), dan kewajiban memenuhi (obligation to fulfil).

Namun khusus dalam hak-hak ekonomi, sosial dan budaya seperti hak atas pekerjaan, negara lebih terlibat dengan kewajibannya untuk memenuhi hak-hak tersebut. Pemerintah diwajibkan [a] menyusun perencanaan dan langkah-langkah (to take steps) berdasarkan indikator hasil sebagai kewajiban berbuat (obligation of conduct), dan [b] merealisasikan atas apa yang sudah direncanakan dengan memaksimalkan ketersediaan sumber daya (to the maximum of their available resources) sebagai kewajiban meraih hasil (obligation of result). Dengan demikian, negara (state) dalam memenuhi hak-hak ekonomi, sosial dan budaya bersifat sebagai realisasi yang progresif (progressive realization). Berdasarkan konsep dan norma hak-hak manusia, tidaklah menjadi kewajiban pihak lain kecuali negara, terutama pemerintah yang menanggung kewajiban dan tugas untuk merealisasikan pemenuhan hak-hak ekonomi, sosial dan budaya,

40 Naning Mardiniah, Harry Wibowo, Rahadi T Wiratama, dan Wildan Pramudia, Memeriksa Kewajiban Negara: Instrumen Monitoring Hak atas Pendidikan dan Kesehatan, Jakarta: LP3ES, 2006, hal. 1. 
khususnya hak atas pekerjaan.

Bukan masalah harga tetapi keberlanjutan, inilah tantangan terbesar itu sekarang. Seperti tembakau dan rokok itu sendiri, akibat rezim perdagangan bebas dunia yang kuasa kini, istilah 'proteksi', 'subsidi', 'pembatasan tarif', dan semacamnya, sudah menjadi barang najis yang diharamkan. Meskipun dalam praktik nyatanya, terlalu banyak agenda terselubung, kemunafikan dan 'ukuran ganda' (dual standard) disebaliknya. Kini kita semakin sering melontarkan kekaguman pada teladan ekonomi dan industri Cina dan India yang suka 'mbalelo menerapkan tafsir dan takrif makna mereka sendiri atas semua imperatif rezim kuasa dunia tersebut tetapi kita terlalu loyo untuk lebih bernyali, punya 'kemauan dan keberanian politik', untuk melakukan tindakan yang sama.

\section{E. Kesimpulan}

Dibalik kesuksesan tembakau sebagai salah satu komoditas yang memiliki sumbangsih besar terhadap penerimaan negara, pemerintah justru mengeluarkan beberapa kebijakan yang menentang terhadap perkembangan pemasaran tembakau khususnya rokok. Terdapat beberapa kebijakan pemerintah yang dinilai menentang terhadap perkembangan produk-produk tembakau dikalangan masyarakat, antara lain: (1) Peraturan Pemerintah Nomor 109 Tahun 2012 tentang Pengaman Bahan yang Mengandung Zat Adiktif Berupa Produk Tembakau Bagi Kesehatan; (2) Peraturan Bersama Menteri Dalam Negeri NOMOR 188/MENKES/PB/I/2011 tentang Pedoman Pelaksanaan Kawasan Tanpa Rokok (KTR).

Cara melihat persoalan tembakau dari sudut pandang kesehatan dengan meniadakan perspektif lainnya ini bukan hanya tidak tepat melainkan justru menyesatkan. Alasannya, tembakau adalah barang legal dan komoditi unggulan yang mempunyai peran vital dengan pertautan kepentingan ekonomi, sosial dan budaya. Pemaksaan perspektif kesehatan secara terus-menerus melalui kampanye serta mengukuhkannya dalam bentuk regulasi berpeluang membawa persoalan tembakau menjadi masalah sosial yang lebih besar. Ambruknya industri kretek akan mengakibatkan jutaan petani tembakau, cengkeh dan buruh kehilangan pekerjaan dan negara tak mempunyai sumber pendapatan besar untuk pembangunan. Dengan demikian pemerintah belum bisa menjadi mengakomodir hak-hak manusia (buman rights) hak-hak ekonomi, sosial dan budaya. 


\section{Bibliografi}

\section{Buku;}

Ambariyanto dan Herawati N, Pengembangan Kelembagaan Pemasaran Komoditas Tembakau terhadap Kesejahteraan Petani di Kabupaten Sumenep, Jurnal Akuntansi, Manajemen Bisnis dan Sektor Publik, 2010.

Brata, Wisnu, Tembakau atau Mati: Kesaksian, Kegelisahan, dan Harapan Seorang Petani Tembakau. Jakarta: Indonesia Berdikari, 2012.

Direktorat Jendral kekayaan Intelektual Kementrian Hukum dan Hak Asasi Manusia R.I., Indikasi Geografis Terdaftar, Direktorat Jenderal Kekayaan Intelektual - Kementerian Hukum dan HAM R.I., 2018.

Hadi, Syamsul, dkk., Kudeta Putih: Reformasi dan Pelembagaan Kepentingan Asing dalam Ekonomi Indonesia. Jakarta: Indonesia Berdikari, 2012.

Hamilton, Wanda, Nicotine War: Perang Nikotin dan Para Pedagang Obat, Yogyakarta: INSISTPress, 2010.

Hanusz, Mark, Kretek: The Culture and Heritage of Indonesia's Clove Cigarette, Jakarta: Equinox, 2000.

Komisi Nasional Hak Asasi Manusia, Naskah Akademik Rancangan Undang-Undang tentang Pengesahan Framework Convention on Tobacco Control (Konvensi Kerangka Kerja Pengendalian Tembakau), Jakarta: KomnasHAM, 2012.

Laily, Elva, Srinthil Pusaka Saujana Lereng Sumbing, Yogyakarta: Pustaka Indonesia, 2016.

Mardiniah, Naning, Harry Wibowo, Rahadi T Wiratama, dan Wildan Pramudia, Memeriksa Kewajiban Negara: Instrumen Monitoring Hak atas Pendidikan dan Kesehatan, Jakarta: LP3ES, 2006.

Margana, Sri, Kretek Indonesia: Dari Nasionalisme Hingga Warisan Budaya. Yogyakarta: Puskindo, 2014.

Puthut E.A, Hikayat Negeri Tembakau, National Geographic Indonesia, Desember 2012.

Topatimasang, Roem, Puthut EA, dan Hasriadi Ary, (eds.), Kretek: Kajian Ekonomi dan Budaya 4 Kota, Yogyakarta: INSISTPress, 2010.

Wibisono, Nuran, Marlutfi Yoandinas, Kretek: Kemandirian dan Kedaulatan Bangsa Indonesia, Perpustakaan Nasional: Katalog Dalam Terbitan (KDT), 2014. 


\section{Media Online;}

Antara, Ribuan Petani Tembakau Temanggung Demo ke Jakarta, antaranews.com, Selasa, 12 Juli 2011 |18:37 WIB, Diakses pada 17 Februari 2018 Pukul 14.00 WIB.

Antara, Tembakau Dapat Hasilkan Protein Anti-Kanker, antaranews.com, Kamis, 14 Juni 2007 | 00:47 WIB, Diakses pada 17 Februari 2018 Pukul 19.30 WIB.

Bisnis Jateng, Petani tembakau Temanggung menuju Jakarta, bisnis-jateng.com, Senin, 2 Juli 2012, Diakses pada 17 Februari 2018 Pukul 16.15 WIB.

Boleh Merokok, Srinthil, bolehmerokok.com, diakses pada 10 Februari 2018 pukul 13.13 WIB.

Budiah Sari Siregar, Tembakau Manfaat yang Terlupakan, analisadaily.com, Senin, 06 Agustus 2012 | 00:04 WIB, Diakses pada 17 Februari 2018 Pukul 20.10 WIB.

Cerita Indonesia Jalan Jalan Menikmati Negeri Pelangi, Srinthil, Tembakau Paling Mahal Ada Di Indonesia, dalam ceritaindonesia.web.id, April 42014 / Irwan Wahyu Tedjo, diakses pada 10 Februari 2018 pukul 13.08 WIB.

Desa Tilir Kecamatan Tlogomulyo Kabupaten Temanggung, Tembakau Srintil Tlilir Tetap Jadi Primadona Desa, dalam tlilir-tlogomulyo.temanggungkab.go.id Pada: 17 Mei 2016 18:14:16 WIB, diakses 10 Februari 2018 pukul 13.00 WIB.

Detik, Ribuan Petani Demo di Temanggung, Tolak RPP Tembakau, detik.com, Kamis, 22 Desember 2011 |11:03WIB, Diakses pada 17 Februari 2018 Pukul 14.15 WIB.

Gatra, Tembakau untuk Obat Kencing Manis, gatra.com, Kamis, 16 April 2009, Diakses pada 17 Februari 2018 Pukul 20.00 WIB.

Kompas, Kemenko Kesra: RPP Tembakau untuk Memproteksi Generasi Muda, Rabu, 4 Juli 2012, | 16:39 WIB, kompas.com, Diakses pada 16 Februari 2018 Pukul 13.00 WIB.

Kompas, Petani Tembakau Ancam Blokade Jalan, kompas.com, Selasa, 8 November 2011 | 12:44 WIB. Diakses pada 17 Februari 2018 Pukul 14.10 WIB.

Kompas, Petani Tembakau Dihambat, Impor Tak Dihalangi, bisniskeuangan.kompas.com, Kamis, 10 Januari 2013 | 14:27 WIB, Diakses pada 17 Februari 2018 Pukul 13.00 WIB.

Kompas, Ribuan Petani Tembakau Jateng Turun ke Jalan, kompas.com, Kamis, 22 Desember 2011 | 07:24 WIB, Diakses pada 17 Februari 2018 Pukul 14.45 WIB.

Kontan, Pabrik Rokok Kurang Pasokan Tembakau, industri.kontan.co.id, Minggu, 03 April 2011| 13:22 WIB, Diakses pada 17 Februari 2018 Pukul 13.05 WIB.

Liputan 6, Petani Tembakau Protes Fatwa Haram Rokok, liputan6.com, Jumat, 12 Maret $2010 \mid$ 14:08 WIB, Diakses pada 17 Februari 2018 Pukul 17.30 WIB.

Liputan 6, PP Tembakau Bikin Impor Tembakau Naik 20 Ribu Ton, bisnis.liputan6.com, Selasa, 
05 Februari 2013| 19:31 WIB, Diakses pada 17 Februari 2018 Pukul 13.15 WIB.

Suara Merdeka, Petani Tembakau Jateng Sambangi DPR, suaramerdeka.com, Rabu, 04 Juli 2012 | 18:46 WIB, Diakses pada 17 Februari 2018 Pukul 16.30 WIB.

Suara Merdeka, 15 Ribu Petani Tembakau Gunung Sindoro Demo Tolak PP 109, suaramerdeka. com, Rabu, 20 Februari 2013 | 01:45 WIB, Diakses pada 17 Februari 2018 Pukul 17.15 WIB.

Tempo, Benarkah Merokok Ada Manfaatnya?, Jumat, 21 Desember 2012 | 07:00 WIB, tempo. com, Diakses pada 16 Februari 2018 Pukul 13.10 WIB.

Viva, PP Tembakau Disahkan, Apa yang Dilarang?, viva.co.id, Rabu, 9 Januari 2013|10:53WIB, Diakses pada 17 Februari 2018 Pukul 20.20 WIB.

\section{Karya Ilmiah;}

Penelitian dari Universitas Adelaide, Australia, muncul dalam jurnal Arthritis \& Rheumatism, Jurnal Thrombosis Research, edisi Oktober 2010.

Pusat Penelitian Bioteknologi Lembaga Ilmu Pengetahuan Indonesia (LIPI), Dr Arief Budi Witarto M.Eng. 
